\title{
Strategi Imitasi dan Perilaku Konsumen Rokok Country
}

\author{
Oleh: \\ Berri Brilliant Albar \\ Fakultas Ekonomi Universitas Tamansiswa Padang \\ berribet@gmail.com
}

\begin{abstract}
This research is purposed to analyze the factors which influence the consumers in purchasing imitate product. In this case refer to Country cigarettes that success in national market because its appearance features tend look like Marlboro cigarettes. Consumer behavior influenced by marketing stimuli from the marketer of imitation product including the product that look a like the market lader, close packaging feature with market leader do, the same distribution strategy with market leader. Beside all of that factors, it is also influenced by attitude, referring group, and life style that comes from the customers. The research population is the Country cigarrettes's consumers in Andalas University which know about Marlboro and the sample was taken with simple random sampling method of population. The responden are 100 persons. Research analysis data using double regression analysis technique. After all data is collected then it processed with SPSS (Statistical Package for the Social Sciences) program in case to be examined statistical by doing the statistical test. The result of research shows that same packaging with market leader do not have any positive influence and significant to wants in buying, meanwhile attitude variable have negative influence to wants to repeating buying. But, product that look a like the market leader, cheaper price, same promotion with market leader and same distribution strategy with market leader have positive influences and significant to wants of consumer to repeat buying the product.
\end{abstract}

Keywords: imitation, consumer behavior

\section{LATAR BELAKANG}

Tingginya asosiasi sebuah merek produk yang sudah terlanjur melekat kuat di masyarakat akhirnya membuat produk sejenis lainnya sulit untuk bergerak. Yang dapat dilakukan perusahaan adalah menggunakan berbagai sumber yang dimiliki oleh perusahaan untuk menciptakan keunggulan bersaing. Salah satu caranya adalah dengan melakukan pengembangan produk-produk yang inovatif yang tentunya dapat memenuhi selera konsumen yang cenderung berubah.

Namun, untuk Menciptakan sebuah produk baru tentunya memerlukan proses panjang yang meliputi riset dan pengembangan, biaya 
mendidik pasar, promosi besar-besaran, dan hal lainnya (Syafrizal, 2001). Untuk lebih mudahnya perusahaan dapat memilih untuk menggunakan strategi imitasi yang dapat menghindarkan perusahaan dari proses panjang dan kemungkinan kegagalan produk karena tidak potensial. Bahkan Levitt (1969) berpendapat bahwa strategi imitasi atau peniruan produk mungkin sama menguntungkannya dengan strategi inovasi produk.

Strategi imitasi memiliki berbagai tingkatan mulai dari creatif adaptation sebagai tingkatan tertinggi, dimana perusahaan peniru berupaya meniru produk yang ada lalu mengembangkan dan mengadaptasikan pada lingkungan baru (Schnaars, 1994). Pada tingkatan terbawah disebut counterfeits atau pembajakan, dimana perusahaan peniru benar-benar menirukan produk dengan merek serta dengan tampilan produk yang benar-benar sama sehingga sering disebut produk palsu, imitasi pada tingkatan ini ilegal dan melanggar hak kekayaan intelektual (HaKI).

Tingkatan imitasi lainnya yang cukup rentan adalah imitasi trade dress atau design copy, dimana tingkatan ini berada di garis batas antara ilegal dan legal merujuk kepada lemahnya hukum tentang perlindungan hak kekayaan intelektual (HaKI) di Indonesia, dalam istilah barunya imitasi ini disebut comuflage atau kamuflase produk karena kemampuannya untuk berkamuflase dan membingungkan konsumen sehingga melakukan kesalahan dalam pengambilan keputusan. Strategi kamuflase produk ini cukup banyak digunakan oleh perusahaan di Indonesia dalam memasarkan produknya dan terbukti cukup sukses. Tidak hanya digunakan oleh follower seperti rokok Country (yang mirip dengan Marlboro) yang sukses menempati posisi kedua untuk market share rokok putih di Indonesia, bahkan market leader seperti Indofood pun menggunakan strategi ini dalam produk Supermi Sedaaap karena terusik oleh produk Wingsfood dengan merek Sedaap (hanya berbeda satu huruf a).

Selain memperhatikan dari sisi internal perusahaan, tentunya perusahaan juga harus melihat dari sisi konsumen. Perusahaan harus menyadari bahwa setiap konsumen mempunyai perilaku yang berbeda-beda, dan sangat menentukan dalam proses pembelian. Perilaku konsumen dapat didefinisikan sebagai "kegiatan-kegiatan individu yang 
secara langsung terlibat dalam mendapatkan, mengonsumsi, dan menghabiskan produk dan jasa termasuk didalam proses pengambilan keputusan yang mendahului dan menyusuli penentuan kegiatan tersebut (Angel, Blackwell, \&Winiard, 1994)".

Kesuksesan dari strategi inilah yang melatarbelakangi penulis untuk meneliti dari sudut pandang konsumen karena strategi ini bersentuhan langsung dengan kejelian konsumen dalam memandang sebuah produk. Penelitian ini diberi judul "Strategi Imitasi dan Perilaku Konsumen Rokok Country”.

\section{Tujuan Penelitian}

1. Untuk mengetahui bagaiman respon konsumen terhadap produk imitasi.

2. Untuk mengetahui faktor-faktor yang paling dominan yang mempengaruhi konsumen dalam melakukan pembelian produk imitasi.

\section{Strategi Imitasi}

Menurut Kotler (2000), strategi imitasi merupakan strategi pengikut pasar dalam upayanya untuk mempertahankan dan meningkatkan pangsa pasar. Imitasi dapat dilakukan perusahaan dengan berperan sebagai pemalsu, pengklon, peniru, atau pengadaptasi.
Schnaars (1994), menyatakan bahwa strategi imitasi merupakan strategi yang biasanya digunakan oleh later entry untuk memasuki pasar dengan melewatkan proses yang dilakukan oleh innovator. Imitator biasanya memasuki pasar dengan meniru dari innovator.

Menurut Schnaars (1994), secara umum strategi imitasi mengombinasikan tiga strategi, yaitu:

a. Lower prices, yaitu menjual produk dengan harga yang lebih rendah dari produk pioneer. Hal ini sangat memungkinkan karena imitator tidak membutuhkan biaya untuk riset pasar serta biaya promosi yang rendah.

b. Sell a supperior product, yaitu menjual produk yang bisa lebih baik atau sudah disempurnakan dari produk pioneer.

c. Use their market power to overhelm the weaker pioneer, yaitu menyerang pioneer secara langsung di pasar terutama pioneer yang memiliki posisi lemah.

\section{Produk Imitasi dan Tingkatannya}

Menurut Syafrizal (2001), produk imitasi merupakan produk yang diciptakan dengan mengacu atau meniru pada produk pionir. Imitasi dapat 
dilakukan dengan meniru disain, membuat produk generik dengan harga yang lebih murah, dan melakukan beberapa penyempurnaan dari produk terdahulu.

$$
\text { Schnaars (1994) berpendapat }
$$

bahwa produk imitasi merupakan produk yang memasuki pasar dengan mengimitasi produk pioneer (inovator). Imitasi tersebut dapat dilakukan dengan membajak sampai kepada membuat produk yang lebih baik dengan dasar produk pioneer. Schnarrs (1994) menggolongkan imitasi produk pada beberapa tingkatan, yaitu:

\section{Counterfits atau pembajakan}

Pada tingkatan ini perusahaan benarbenar menjual produk dengan merek dan desain produk yang benar-benar sama sehingga sering disebut produk palsu. Imitasi ini tergolong ilegal.

\section{Knockoff atau kloning}

Pada tingkatan ini perusahaan benarbenar meniru produk yang sudah ada tetapi memiliki merek yang lain.

\section{Design copy atau trade dress}

Kemasan, tampilan, atau disain merupakan bagian yang penting dari produk yang menggunakan strategi ini. Selanjutnya peniruan disain dipadukan dengan imitasi dan inovasi.
Namun, jika desain atau kemasan bukan bagian yang penting, maka yang dapat ditiru adalah teknologi atau keunikan dari produk yang menjadi acuan. Pada tingkatan ini perusahaan menciptakan produk yang sangat menyerupai produk lain atau biasanya produk pionir atau market leader tetapi tidak benar-benar sama. Pada tingkatan ini sering juga disebut sebagai kombinasi antara strategi imitasi dan inovasi. Sesuai fungsinya untuk mengelabui konsumen sehingga melakukan kesalahan dalam pembelian, maka produk ini dapat juga disebut dengan istilah produk kamuflase. Strategi ini biasanya digunakan oleh pengikut pasar agar dapat menghindari berbagai biaya sehingga dapat berhadapan langsung dengan market leader karena strategi ini cenderung untuk menciptakan produk yang hampir sama dengan market leader, tetapi dengan harga yang lebih rendah. Contohnya dapat dilihat pada motor Cina ketika memasuki pasar Indonesia, mereka berusaha menyamai disain dan tampilan dengan motor Jepang yang menjadi market leader, hasilnya pangsa pasar motor Honda 
turun sepuluh persen. Namun, strategi ini terbukti cukup aman, karena pada dasarnya hampir seluruh produk di dunia merupakan hasil tiruan. Saat ini boleh saja sepeda motor Jepang menuduh sepeda motor Cina sebagai peniru, namun dulu Eropa dan Amerika juga menuduh mobil Jepang sebagai peniru mobil mereka di akhir 1990. Menurut Kotler (2000), komponen utama strategi imitasi pada produk kamuflase dalam merebut perhatian konsumen adalah:

a. Packaging yang dibuat mirip dengan market leader. Hal ini dilakukan untuk megelabui konsumen scara visual.

b. Promosi yang sama dengan market leader. Hal ini dilakukan untuk memberikan kesan atau positioning yang sama dibenak konsumen dengan produk yang menjadi market leader.

c. Produk baru yang sama dengan market leader. Menciptakan produk yang sama atau lebih baik dibandingkan produk market leader.

d. Harga yang lebih murah dibandingkan market leader. Harga merupakan hal yang cukup menjadi pertimbangan bagi konsumen.

e. Merek yang hampir sama dengan market leader. Untuk beberapa produk terkadang hanya berbeda satu atau dua huruf dengan merek market leader.

f. Strategi distribusi yang sama dengan market leader. Biasanya produk imitasi cenderung mengawali proses ini dengan menjadi saluran distribusi dari produk market leader, seperti Wings yang menjadi saluran distribusi dari Rinso (produk Uniliver), setelah berakhirnya kontrak dengan Uniliver terbukti Wings dapat meniru Rinso dan menghasilkan SoKlin.

Imitasi jenis ini berada diantara daerah ilegal dan legal. Hal ini sangat tergantung pada kemampuan inovasi perusahaan, selain itu faktor hukum yang berlaku disuatu negara merupakan hal yang perlu diperhatikan oleh perusahaan. Undang-undang dibidang trade dress cenderung mengacu pada hak akan kekayaan intelektual (HaKi) untuk menghindari adanya penjiplakan. 


\section{Creative adaptations}

Perusahaan peniru berupaya meniru produk yang ada, kemudian mengembangkan atau mengadaptasikannya kepada lingkungan yang baru.

\section{Perilaku Konsumen}

Menurut Mowen \& Minor (2001) perilaku konsumen didefinisikan sebagai studi tentang unit pembelian (buying units) dan proses penukaran yang melibatkan perolehan, konsumsi dan pembuangan barang, jasa pengalaman serta ide-ide.

Sedangkan menurut Kotler (2005) perilaku konsumen adalah perilaku mempelajari bagaimana individu, kelompok, dan orang-orang memilih, membeli, memakai, dan membuang barang, jasa, dan gagasan atau pengalaman dalam rangka memuaskan kebutuhan dan hasrat mereka.

Proses penukaran merupakan unsur utama dari perilaku konsumen. Penukaran terjadi antara konsumen dengan perusahaan, disamping itu juga terjadi antara perusahaan pada situasi pembelian industrial dan pertukaran yang terjadi antara konsumen itu sendiri.
Jadi, ada tiga faktor yang harus diperhatikan dalam permintaan pasar untuk produk atau jasa yaitu, orang-orang dengan kebutuhan, daya beli mereka, dan perilaku beli mereka.

\section{Faktor-Faktor yang mempengaruhi Perilaku konsumen}

Pembelian konsumen sangat dipengaruhi oleh karakteristik budaya, sosial, pribadi, dan psikologis (Angel, Blackwell, dan Winiard, 1994).

1. Budaya

Setiap Budaya terdiri dari sub-sub budaya yang lebih kecil yang memberikan identifikasi dan sosialisasi anggotanya yang lebih spesifik. Sub budaya ini timbul karena faktor ras, kebangsaan, agama, lokasi geografi, distribusi pedesaan, urban, dan sebagainya.

\section{Sosial}

Tingkah laku konsumen juga dipengaruhi oleh faktor-faktor sosial antara lain :

a. Kelompok Acuan. Perilaku seseorang dipengaruhi oleh banyak kelompok. Kelompok acuan seseorang terdiri dari semua kelompok yang mempunyai pengaruh langsung 


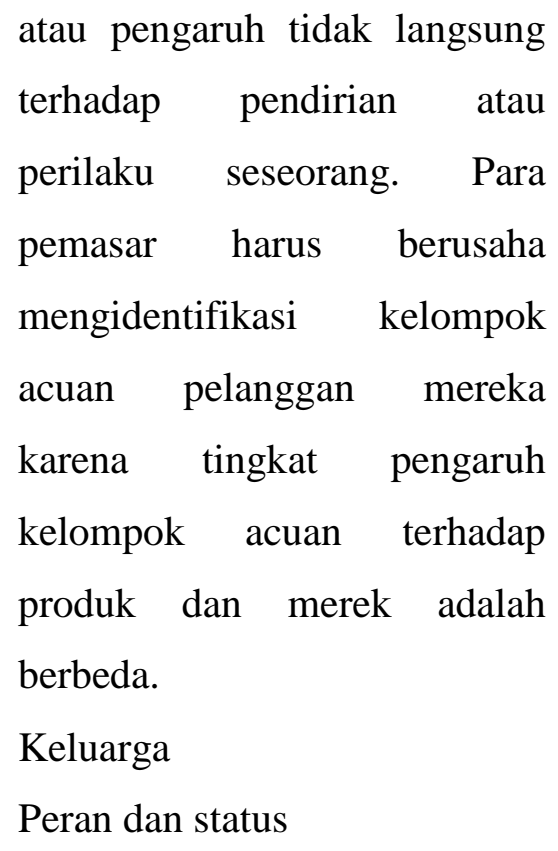

3. Pribadi

Keputusan membeli juga dipengaruhi oleh karateristik pribadi pembeli, yakni :

a. Umur dan Tahap Daur Hidup

b. Pekerjaan

c. Situasi Ekonomi

d. Gaya Hidup, adalah pola kehidupan seseorang yang diwujudkan dalam aktivitas, minat, dan pendapatnya. Aktivitas menyangkut pekerjaan, hobi, berbelanja, olah raga, dan kegiatan sosial. Minat menyangkut makanan, mode, keluarga, rekreasi. Sedangkan opini menyangkut mengenai diri mereka sendiri, isu sosial, bisnis, dan produk. Konsep gaya hidup dapat membantu pemasar memahami nilai-nilai konsumen yang berubah dan bagaimana pengaruhnya pada tingkah laku membeli.

e. Kepribadian dan Konsep Diri

4. Psikologis

Pilihan produk yang dibeli seseorang dipengaruhi oleh faktor psikologis antara lain:

a. Motivasi

b. Persepsi, didefinisikan sebagai proses bagaimana seseorang menyeleksi, mengatur dan menginterprestasikan masukan-masukan informasi untuk menciptakan gambaran keseluruhan yang berarti (Kotler, 2000). Seseorang yang termotivasi akan siap untuk bertindak. Bagaimana seseorang termotivasi untuk bertindak akan dipengaruhi oleh persepsinya terhadap sesuatu.

c. Pembelajaran

d. Keyakinan dan sikap

Keyakinan adalah pemikiran deskriptif yang dimiliki seseorang mengenai sesuatu. Sikap menguraikan evaluasi, 
perasaan, dan kecenderungan

dari seseorang terhadap suatu objek atau ide yang relatif konsisten (Kotler dan Gary, 1996). Melalui pembelajaran orang mendapatkan keyakinan dan sikap, yang akan mempengaruhi tingkah laku seseorang dalam membeli.

Menurut Keegan (1995) dalam

Cross-cultural Consumer

Characterizationcs terdapat proses psikologis yang terlibat dalam tingkah laku manusia mendasar yang tidak dipengaruhi oleh budaya dan demikian mendasar, sehingga dapat ditemui diseluruh dunia. Pengelompokan terdiri atas tujuh kelompok yaitu: resigned poor, struggling poor, mainstreamer, aspirer, succeder, transitional, dan reformer. Dalam faktor sikap, mahasiswa digolongkan pada kategori transitional dimana cenderung memiliki sikap bebas dan pemberontak.

\section{METODOLOGI PENELITIAN}

\section{Populasi dan Sampel}

Populasi meliputi seluruh konsumen rokok Country di kalangan mahasiswa S1 Fakultas Ekonomi Universitas Andalas yang mengetahui rokok Marlboro. Metode pengambilan sampel yang digunakan adalah convenient sampling yaitu sampel yang dapat ditemui dengan mudah, sebanyak 100 responden. Karena jumlah populasi dari konsumen rokok yang tidak teridentifikasi jumlahnya, maka jumlah yang dianjurkan adalah antara 50-100 sampel (Santoso, 2002: hal 94). Guilford (1987) dalam Alimunir menyebutkan persyaratan minimal untuk sampel adalah hanya 30 responden, namun semakin besar sampel akan memberikan hasil yang lebih akurat. Pada penelitian ini peneliti menetapkan jumlah sampel yang akan digunakan sebanyak 100 responden.

Pengambilan data dilakukan dengan cara memberikan kuisioner kepada responden yang ada disekitar peneliti. Sebelum kuisioner diberikan, calon responden ditanyai apakah mereka pernah mengonsumsi rokok Country dan mengetahui rokok Marlboro. Jika tidak maka ia digugurkan sebagai responden. 


\section{Variabel Penelitian}

Di dalam penelitian ini variabel penelitian terdiri atas dua jenis variabel, yaitu variabel bebas (independent variable) dan variabel tidak bebas (dependent variable).

1. Variabel Bebas (Independent Variable)

Variabel bebas dalam penelitian ini adalah komponen utama strategi imitasi dalam merebut perhatian konsumen (marketing stimuli) dan Faktor perilaku konsumen, yaitu:

a. Kemiripan packaging dengan market leader.

b. Kesamaan promosi dengan market leader.

c. Kesamaan produk dengan market leader.

d. Harga yang lebih murah dibandingkan market leader.

e. Kesamaan strategi distribusi dengan market leader.
f. Sikap
g. Kelompok acuan
h. Gaya hidup

2. Variabel Tidak Bebas (Dependent Variable)

Adapun variabel tidak bebas (dependent variable) dalam penelitian ini adalah niat untuk membeli lagi rokok Country yakni suatu keputusan yang diambil seorang pembeli menyangkut kepastian apakah akan membeli produk lagi atau tidak.

\section{Model Penelitian}

Penelitian ini akan menggunakan model sebagai berikut: 


\section{Gambar 1. Model Penelitian}

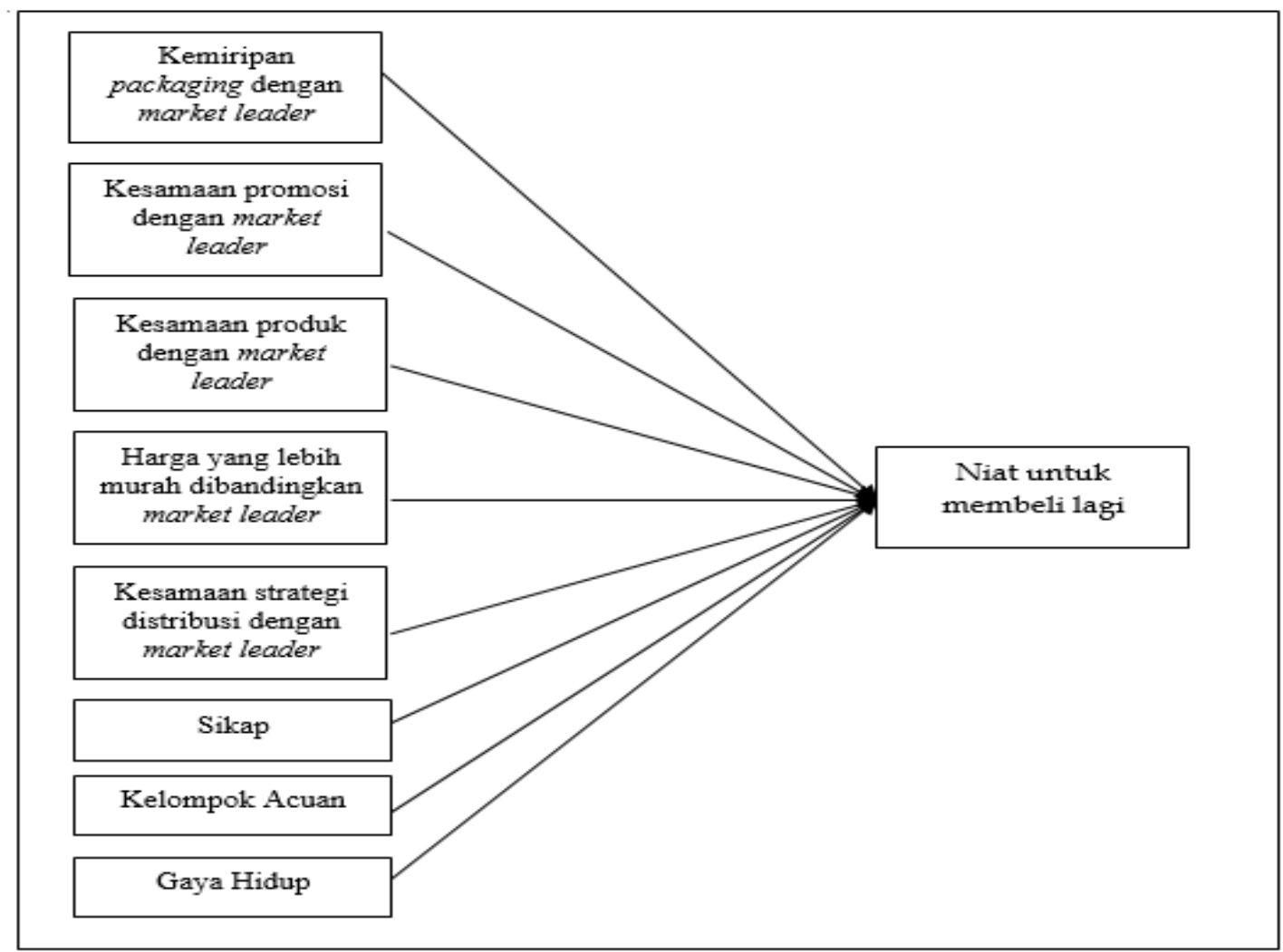

Sumber: Olahan Sendiri

\section{HASIL PENELITIAN DAN PEMBAHASAN}

\section{Uji T-Test}

Tabel 1. Uji T-Test

\begin{tabular}{|c|c|c|c|c|c|c|c|c|}
\hline \multicolumn{9}{|c|}{ Coefficients $^{a}$} \\
\hline \multirow{2}{*}{\multicolumn{2}{|c|}{ Model }} & \multicolumn{2}{|c|}{$\begin{array}{c}\text { Unstandardized } \\
\text { Coefficients }\end{array}$} & \multirow{2}{*}{$\begin{array}{c}\begin{array}{c}\text { Standardized } \\
\text { Coefficients }\end{array} \\
\text { Beta } \\
\end{array}$} & \multirow[b]{2}{*}{$\mathrm{t}$} & \multirow[b]{2}{*}{ Sig. } & \multicolumn{2}{|c|}{ Collinearity Statistics } \\
\hline & & $\mathrm{B}$ & Std. Error & & & & Tolerance & VIF \\
\hline \multirow[t]{9}{*}{1} & (Constant) & -1.596 & 1.648 & & -.968 & .336 & & \\
\hline & PACKAGING & .033 & .133 & .015 & .251 & .802 & .658 & 1.519 \\
\hline & PROMOTION & .410 & .087 & .274 & 4.724 & .000 & .660 & 1.516 \\
\hline & PRODUCT & .576 & .086 & .396 & 6.678 & .000 & .630 & 1.588 \\
\hline & PRICE & 270 & .055 & 291 & 4.890 & .000 & .627 & 1.596 \\
\hline & PLACE & .553 & .151 & .224 & 3.666 & .000 & .594 & 1.685 \\
\hline & SIKAP & -.367 & .120 & -.207 & -3.062 & .003 & .486 & 2.060 \\
\hline & KELOMPOK ACUAN & .394 & .128 & .198 & 3.085 & .003 & .538 & 1.857 \\
\hline & LIFESTYLE & .210 & .072 & .173 & 2.938 & .004 & .640 & 1.562 \\
\hline
\end{tabular}

a. Dependent Variable: PEMBELIAN KONSUMEN

Sumber: Output SPSS 12.0 
Hasil penelitian dan pembahasan yang dilakukan tentang faktor-faktor yang mempengaruhi konsumen dalam membeli produk imitasi (studi kasus: rokok Country) menghasilkan bentuk persamaan regresi sebagai berikut:

$\mathrm{Y}=-1.595+0.033 \mathrm{X} 1+0.410 \mathrm{X} 2+0.576 \mathrm{X} 3+0.270$ $\mathrm{X} 4+0.553 \mathrm{X} 5-0.367 \mathrm{X} 6+0.394 \mathrm{X} 7+0.210 \mathrm{X} 8$

Dari hasil regresi diatas dapat disimpulkan bahwa packaging(X1) tidak memliki pengaruh yang positif terhadap niat untuk membeli lagi (Y). Begitu juga dengan sikap (X6) yang memiliki pengaruh negatif terhadap niat untuk membeli lagi (Y). Sementara, promotion (X2), product (X3), price (X4), place (X5), kelompok acuan (X7), dan gaya hidup (X8) memliki pengaruh yang positif terhadap niat untuk membeli lagi (Y).

Untuk uji $\mathrm{t}$, diperoleh nilai $\mathrm{t}$ hitung variabel X1 sebesar 0.251 sedangkan $\mathrm{t}$ tabel pada alpha $5 \%$ dan $\mathrm{df}=$ 92 adalah 1,986 ( $\mathrm{t}$ hitung $<\mathrm{t}$ tabel), berarti diperoleh koefisien korelasi yang tidak signifikan. Jadi dapat disimpulkan bahwa variabel packaging (X1) tidak memiliki pengaruh yang positif dan signifikan terhadap variabel niat untuk membeli lagi.
Untuk uji t, diperoleh nilai $t$ hitung variabel X2 sebesar 4.724 sedangkan $\mathrm{t}$ tabel pada alpha $5 \%$ dan $\mathrm{df}=$ 92 adalah 1,986 ( $\mathrm{t}$ hitung $>\mathrm{t}$ tabel), berarti diperoleh koefisien korelasi yang signifikan. Jadi dapat disimpulkan bahwa variabel promotion (X2) memiliki pengaruh yang positif dan signifikan terhadap variabel niat untuk membeli lagi.

Untuk uji $t$, diperoleh nilai $t$ hitung variabel X3 sebesar 6.678 sedangkan $\mathrm{t}$ tabel pada alpha $5 \%$ dan $\mathrm{df}=$ 92 adalah 1,986 ( $\mathrm{t}$ hitung $>\mathrm{t}$ tabel), berarti diperoleh koefisien korelasi yang signifikan. Jadi dapat disimpulkan bahwa variabel product $(\mathrm{X} 3)$ memiliki pengaruh yang positif dan signifikan terhadap variabel niat untuk membeli lagi.

Untuk uji $\mathrm{t}$, diperoleh nilai $\mathrm{t}$ hitung variabel $\mathrm{X} 4$ sebesar 4.800 sedangkan t tabel pada alpha $5 \%$ dan $\mathrm{df}=$ 92 adalah 1,986 ( $\mathrm{t}$ hitung $>\mathrm{t}$ tabel), berarti diperoleh koefisien korelasi yang signifikan. Jadi dapat disimpulkan bahwa variabel price (X4) memiliki pengaruh yang positif dan signifikan terhadap variabel niat untuk membeli lagi.

Untuk uji $\mathrm{t}$, diperoleh nilai $\mathrm{t}$ hitung variabel X5 sebesar 3.666 sedangkan $\mathrm{t}$ tabel pada alpha $5 \%$ dan $\mathrm{df}=$ 
92 adalah 1,986 (t hitung > t tabel), berarti diperoleh koefisien korelasi yang signifikan. Jadi dapat disimpulkan bahwa variabel place (X5) memiliki pengaruh yang positif dan signifikan terhadap variabel niat untuk membeli lagi.

Untuk uji $\mathrm{t}$, diperoleh nilai $\mathrm{t}$ hitung variabel X6 sebesar -3.602 sedangkan $\mathrm{t}$ tabel pada alpha $5 \%$ dan $\mathrm{df}=$ 92 adalah 1,986 ( $\mathrm{t}$ hitung $<\mathrm{t}$ tabel), berarti diperoleh koefisien korelasi yang signifikan tetapi memiliki pengaruh negatif. Jadi dapat disimpulkan bahwa variabel sikap (X1) memiliki pengaruh yang negatif dan signifikan terhadap variabel niat untuk membeli lagi.

Untuk uji $t$, diperoleh nilai $t$ hitung variabel X7 sebesar 3.085 sedangkan t tabel pada alpha $5 \%$ dan $\mathrm{df}=$ 92 adalah 1,986 ( $\mathrm{t}$ hitung $>\mathrm{t}$ tabel), berarti diperoleh koefisien korelasi yang signifikan. Jadi dapat disimpulkan bahwa variabel kelompok acuan (X7) memiliki pengaruh yang positif dan signifikan terhadap variabel niat untuk membeli lagi.

Untuk uji $\mathrm{t}$, diperoleh nilai $\mathrm{t}$ hitung variabel X8 sebesar 2.938 sedangkan $\mathrm{t}$ tabel pada alpha $5 \%$ dan $\mathrm{df}=$ 92 adalah 1,986 ( $\mathrm{t}$ hitung $>\mathrm{t}$ tabel), berarti diperoleh koefisien korelasi yang signifikan. Jadi dapat disimpulkan bahwa variabel gaya hidup (X8) memiliki pengaruh yang positif dan signifikan terhadap variabel niat untuk membeli lagi.

Dari hasil regresi diatas dapat disimpulkan bahwa variabel produk yang memiliki kesamaan dengan market leader (X3) merupakan faktor yang memiliki pengaruh paling besar terhadap niat untuk membeli lagi (Y) diikuti oleh variabel harga yang lebih murah dibandingkan market leader (X4).

\section{Uji F-Test}

Tabel 2. Uji F-Test

ANOVA

\begin{tabular}{|c|c|c|c|c|c|c|}
\hline \multicolumn{2}{|c|}{ Model } & $\begin{array}{l}\text { Sum of } \\
\text { Squares }\end{array}$ & $\mathrm{df}$ & Mean Square & $\mathrm{F}$ & Sig. \\
\hline \multirow[t]{3}{*}{1} & Regression & 1840.950 & 8 & 230.119 & 44.987 & $.000^{a}$ \\
\hline & Residual & 465.490 & 91 & 5.115 & & \\
\hline & Total & 2306.440 & 99 & & & \\
\hline
\end{tabular}

a. Predictors: (Constant), LIFESTYLE, PRICE, PROMOTION, PACKAGING, KELOMPOK ACUAN, PRODUCT, PLACE, SIKAP

b. Dependent Variable: PEMBELIAN KONSUMEN 
Untuk pengujian secara simultan dengan menggunakan uji F-test menunjukkan nilai $\mathrm{F}$ hitung $44.987>\mathrm{F}$ tabel 2.111 dengan tingkat signifikan $0,000<0,05$. Artinya packaging, promotion, product, price, place, sikap, kelompok acuan, dan gaya hidup secara bersama-sama mempengaruhi niat untuk membeli lagi rokok Country.

\section{Koefesien Determinasi}

Tabel 3. Koefisien Determinasi Model Summary ${ }^{b}$

\begin{tabular}{|l|r|r|r|r|r|}
\hline Model & $\mathrm{R}$ & R Square & $\begin{array}{c}\text { Adjusted } \\
\text { R Square }\end{array}$ & $\begin{array}{c}\text { Std. Error of } \\
\text { the Estimate }\end{array}$ & $\begin{array}{c}\text { Durbin- } \\
\text { Watson }\end{array}$ \\
\hline 1 & $.893^{\mathrm{a}}$ & .798 & .780 & 2.26170 & 1.991 \\
\hline
\end{tabular}

a. Predictors: (Constant), LIFESTYLE, PRICE, PROMOTION, PACKAGING, KELOMPOK ACUAN, PRODUCT, PLACE, SIKAP

b. Dependent Variable: PEMBELIAN KONSUMEN

Sumber: Output SPSS 12.0

Dari hasil pengujian SPSS diketahui: Adjusted $\mathrm{R}^{2}=0.780$, yang berarti bahwa sebesar $78 \%$ niat untuk membeli lagi rokok Country pada mahasiswa Fakultas Ekonomi S1 Universitas Andalas di kota Padang ditentukan oleh packaging, promotion, product, price, place, sikap, kelompok acuan, dan gaya hidup, sedangkan sisanya $22 \%$ dipengaruhi oleh variabel lainnya yang tidak ada dalam penelitian, seperti budaya, motivasi, dan status.

\section{Implikasi Penelitian}

Dari hasil regresi diatas dapat disimpulkan bahwa variabel produk yang memiliki kesamaan dengan market leader merupakan faktor yang memiliki pengaruh paling besar terhadap niat untuk membeli lagi rokok Country.

Dari hasil pengujian data dengan menggunakan analisis regresi berganda diketahui bahwa packaging yang sama dengan market leader tidak memliki pengaruh yang positif terhadap niat untuk membeli lagi. Begitu juga dengan sikap yang memiliki pengaruh negatif terhadap niat untuk membeli lagi. Sementara, promotion yang sama dengan market leader, product yang sama dengan market leader, price yang lebih murah 
dari market leader, place strategi distribusi yang sama dengan market leader, kelompok acuan, dan gaya hidup memiliki pengaruh yang positif dan signifikan terhadap niat untuk membeli lagi rokok Country.

Sikap sebagai evaluasi, perasaan, dan kecenderungan dari responden terhadap rokok Country dalam hasil penelitian ini memiliki pengaruh negatif terhadap niat untuk membeli lagi. Hal ini sesuai dengan teori Keegan (1995) yang menggolongkan mahasiswa (responden) dalam kategori transitional dimana memiliki sikap yang bebas dan pemberontak. Sehingga sikap mahasiswa yang bebas dan pemberontak (berubahubah) karena dalam masa transisi cenderung tidak berpengaruh positif terhadap niat untuk membeli lagi rokok Country.

Dilihat dari masing-masing persentase skor diperoleh bahwa rasa atau kualitas produk Country yang mirip Marlboro menjadi alasan responden untuk membeli rokok Country. Namun, dari segi tar dan nikotinnya tentunya Country perlu menurunkannya karena tar dan nikotin rokok Country lebih tinggi dibanding rokok Marlboro.
Harga merupakan hal yang sangat sensitif bagi mahasiswa sebagai responden penelitian ini. Harga rokok Country yang jauh lebih murah menjadi alasan yang cukup kuat bagi responden yang kebanyakan masih belum memiliki pendapatan sendiri.

Sementara kemasan rokok Country yang mirip Marlboro ternyata tidak begitu memiliki pengaruh yang begitu baik. Hal ini tentunya dapat menjadi masukan bagi Country untuk melepaskan kesan Marlboro yang begitu terlihat pada kemasan sehingga Country tidak lagi terkesan menjadi Marlboro palsu.

\section{Kesimpulan}

1. Produk rokok Country yang menyerupai Marlboro dan ditunjang dengan harga yang lebih murah menjadi alasan utama bagi responden mahasiswa untuk membeli lagi rokok Country.

2. Tingginya respon responden terhadap harga sesuai dengan teori Kotler (2002) yang menyatakan bahwa harga yang lebih rendah merupakan kunci sukses dari strategi imitasi dalam berbisnis. Selain itu tentunya 


\begin{abstract}
ditentukan oleh kondisi perekonomian kebanyakan masyarakat Indonesia atau responden mahasiswa khususnya yang kebanyakan belum memiliki penghasilan. Menurut data Komisi Nasional Pengendalian Tembakau tahun 2006, diyatakan bahwa $63 \%$ pembeli rokok adalah laki-laki miskin yang tentunya cukup mempertimbangkan masalah harga.
\end{abstract}

3. Kemasan rokok Country yang mirip dengan Marlboro ternyata tidak berpengaruh terhadap keputusan pembelian responden.

4. Penelitian ini mempunyai koefisien determinasi yang disesuaikan (adjusted $\mathrm{R}^{2}$ ) sebesar 0,780 yang berarti bahwa sebesar $78 \%$ niat untuk membeli lagi rokok Country pada mahasiswa Fakultas Ekonomi S1 Universitas Andalas di kota Padang ditentukan oleh packaging yang mirip dengan market leader, promotion yang sama dengan market leader, product yang sama dengan market leader, price yang lebih murah dari market leader, place (strategi distribusi) yang sama dengan market leader, sikap, kelompok acuan, dan gaya hidup.

\section{DAFTAR PUSTAKA}

Bentoel. (2007). Country(On-line) Available http://www.bentoel.com

Harapan, Sinar. (2003). Country Incar Posisi Kedua Rokok Putih (Online) Available http://www.sinarharapan.com

Herlina. Hubungan Tipe Strategi Bisnis dan Strategi Pemasaran dalam Menciptakan Keunggulan Bersaing Perusahaan dengan Menggunakan Manajemen Tenaga Penjual, Jurnal Manajemen vol.6, No.1.2006

Hitt, Michael A., dkk. (1997). Manajemen Strategis Menyongsong Era Persaingan dan Globalisasi. Jakarta: Erlangga.

Hou, Wee Chow. (1997). Practical Marketing an Asian Perspective. Jakarta: Mega Media.

Kartajaya, Hermawan. (1999). Marketing Plus 2000 Siasat Memenangkan Persaingan Global. Jakarta: PT. Gramedia Pustaka Utama.

Kartajaya, Hermawan. (2006). Hermawan Kertajaya on Marketing. Jakarta: PT. Gramedia Pustaka Utama.

Kartajaya, Hermawan. (2006). Marketing Klasik Indonesia. Bandung: PT. Mizan Pustaka. 
Keegan, Warren J. (1996). Manajemen Pemasaran Global Edisi Revisi Jilid 1. Jakarta: Prehalindo.

Kotler, Philip, dkk., (2000). Manajemen Pemasaran Perspektif Asia Buku 1. Yogyakarta: Penerbit Andi.

Kotler, Philip. (2000), Marketing Management., $10^{\text {th }}$ Ed. New Jersey: Prentice Hall Inc.

Kotler, Philip. (2002). Manajemen Pemasaran. Terjemahan Hendra Teguh, Ronny A. Rusli dan Benyamin Molan. Jilid II Edisi Milenium. Jakarta: PT Indeks.

Kotler, Philip. (2003). Re-thinking Marketing Sustainable Marketing Enterprise di Asia, Marco P. Widodo (alih bahasa). Jakarta: PT. Prenhalindo.

$$
\begin{gathered}
\text { Majalah } \quad \text { Marketing, } \\
\text { Edisi } \\
26
\end{gathered}
$$

Maryuda, Efri. Pengaruh Faktor Perilaku Konsumen dalam Pengambilan Keputusan Pembelian Rokok Lucky Strike di Kota Padang. Skripsi Fakultas Ekonomi Universitas Andalas, Tidak Diterbitkan. 2006.

Mowen, John C. \& Michael Minor. (2002). Prilaku Konsumen, Terjemahan Lina Salim, SE, MBA, MA, Jilid 1. Jakarta: Erlangga.

Schnaars, Steven p. Managing Imitation Strategy: How Later Entrants Seize Markets From Pioneers, Journal of Marketing vol.59 1995.
Schnaars, Steven p. (1994). Managing Imitation Strategy. New York: The Free Press.

Sekaran, Uma. (2003). Research Methods for Business. New York: John Wiley \& Sons, Inc.

Stanton, William J. (1986). Prinsip Pemasaran Edisi ke-7 Jilid 2. Jakarta: Erlangga.

Sunarto. (2003). Manajemen Pemasaran. Yogyakarta: BPFE-UTS.

Suryabrata, Sumadi., Drs., BA., MA., Ed.S., Ph.D. (2006) Metodologi Penelitian. Jakarta: Raja Grafindo Persada.

Susanta, Rahmat. (2004). Camouflage Marketing (On-line) Available http://www.majalahmarketing.com

Swastha, Basu DH \& Suketjo Ibnu (1995). Pengatar Bisnis Modern. Edisi Ketiga, Yogyakarta: Liberty.

Syafrizal. Manajemen Produk Kontemporer untuk Memenangkan Persaingan Pasar, Jurnal Ekonomi dan Manajemen Fakultas Ekonomi Universitas Andalas no.IX/2. 2001.

Thompson, Strickland. (2001), Strategic Management : Concept and Cases. $12^{\text {th }}$ Ed. New York: McGraw-Hill Companies.

Tjahyudi, Rully A. Brand Trust dalam Konteks Loyalitas Merek: Peran Karakteristik Merek, Karakteristik Perusahaan, dan Karakteristik Hubungan Pelanggan-Merek, 
Jurnal Manajemen dan Kewirausahaan, Volume 9, Nomor 2, Mei 2018

ISSN 2086-5031

E-ISSN 2615-3300

DOI 10.31317

Jurnal Manajemen, vol.6,

No.1.2006

Zhou, Kevin Z. Innovation, Imitation, and New Product Performance:

Wikipedia. (2007). Marlboro (On-line)

Available

http://www.wikipedia.com

The Case of China, Journal of Institute for the study of Business Markets The Pennsylvania State

Winardi, DR., SE. (1989). Kamus University.2-2005

Ekonomi (Inggris-Indonesia).

Bandung: CV. Mandar Maju. 